\title{
Theodor Storm og Danmark (med specielt Henblik paa hans Forhold under Krigen 1848-50.) Af Anna Simonsen.
}

Theodor Storm blev født 1817 i Husum, hvor hans Fader Johann Casimir Storm var Advokat. Han tilhørte altsaa Overklassen, der her ligesom i de andre slesvigske Byer gennemgaaende var orienteret mod Syd. Advokat Storm, der var en af Landsdelens fremtrædende Politikere, repræsenterede $i$ Tidsrummet 1831-46 de liberale i Husum Amt i den slesvigske Stænderforsamling. Der er dog i det mig foreliggende Materiale intet, der kunde tyde paa, at den unge Storm har haft politiske Interesser i sine Skole- og Studenteraar. Hans Studentertid, som han for største Delen tilbragte i Slesvig-Holstenismens Højborg Kiel, faldt dog ellers netop i de Aar, da man var ved at vaagne op til national Bevidsthed. Theodor Storm, der fulgte i Faderens Fodspor med Hensyn til Valget af sit Studium, har tilsyneladende ikke interesseret sig synderlig hverken for Studiet eller for Politik. Han dyrkede med Forkærlighed Litteratur og Musik. I Aaret 1843 udgav han sammen! med to Studenterkammerater, Brødrene Mommsen, en Digtsamling: „Liederbuch dreier Freunde“. Mens man i et af Theodor Mommsens') Digte (Anno 1841) finder tydelige Hentydninger til de politiske Forhold i Landsdelen, bærer Storms Bidrag ikke i mindste Maade Præg af nogen Tilknytning til Hjemstavnen.

Da Storm havde taget sin Embedseksamen i 1842, nedsatte han sig som Advokat i sin Fødeby. Nu faar han efterhaanden en vis Tilknytning til den slesvigholstenske Bevægelse. Bl. a. finder man ham som Medlem af Festkomiteen ved Arrangementet af den store Nordfriserfest i Bredsted den 10. Juni 1844²).

1) Den senere saa bekendte Historiker.

2) Geschichte des am 10. Juny in Bredstedt gefeierten Volksfestes der Nordfriesen. Udgivet af P. Lorenzen. 
Denne Fest skulde være et Forsøg paa at vække Friserne, der hidtil havde vist ringe politisk Interesse, til Opposition mod Regeringen og til tysk Bevidsthed. At den unge Storm dog ikke tog alt dette særlig alvorligt, viser et Brev til hans forlovede, Constance Esmarch i Segeberg ${ }^{3}$ ). Han skriver om den sentimentale Dansker-æder Johannes P. fra Tønder, (det maa være Johannes T., da man i Beskrivelsen af Festen finder Johs. Todsen fra Tønder opført blandt Talerne) der paa denne Dag holdt halvtreds Taler, af hvilke der ikke var Mening i en eneste. Ogsaa andre af Slesvig-Holstenismens Koryfæer faar det glatte Lag. Saaledes skriver han om Advokat B. (kan være baade Beseler og Bremer, idet begge disse Advokater nævnes blandt Talerne) og Doktor N. (hvem Dr. N. er, kan jeg ikke oplyse). De stod højt oppe paa Pavillonens Balkon i Skæret fra Lamperne og Begfaklerne og holdt hinanden omslynget i salig Beruselse, mens de deklamerede ud over Bondeknoldene, der dansede ved deres Fødder:

\section{Brüder überm Sternenzelt muss ein guter Vater wohnen.}

Han er paa ingen Maade fjendtlig indstillet mod Danskerne i disse Aar. Han digter endog Velkomsthyldest til Kong Christian VIII, da denne i Aaret 1845 gæster Husum. Han skriver om dette til Constance Esmarch, at han, hvor upolitisk han end er, dog føler sig forbundet med hele Landet i Sympati. Dog hedder det, ,at han ikke vil indlade sig paa at skamrose Kongen".

Man maa ogsaa indrømme, at Digtet „Heil dir, heil dir, hoher König“4) er ret intetsigende. Det røber intet om Befolkningens Følelser overfor Kongen, af hvad Art disse end maatte være. Man faar af Brevene det Indtryk, at han nærmest giver sig i Lag med Opgaven, fordi den tilfredsstiller hans Digter-

3) Briefe an seine Braut. Udg. af Gertrud Storm.

4) Storms Sämtliche Werke. Udg. af Albert Köster. Bd. I S. 240. 
natur. Man kan i det hele taget sige, at Storm hele sit Liv igennem stedse satte Kunsten højere end Politiken.

Først da Oprørsfanerne er hejst, da den formentlige Fjende er trængt dybt ind i Landsdelen, stiller han sin Digtekunst i det nationales Tjeneste. Paa den Maade mente han at kunne gavne sit Land bedst, mens mange af hans Slægtninge og Venner drog ud i Felten som frivillige. Men Storm bekender, at det ikke er de politiske Digte, der staar hans Hjerte nærmest.

Vi kan vel og i Trompeten støde,

Saa vidt det gjalder over Land.

Dog heller vi vandrer i Majdagen,

Mens Primulaerne blomstrer og Droslerne slaar,

Tænksomt og stille ved Bækkens Rand.

Trods dette mener flere Stormforskere, at hans politiske Lyrik staar paa Højde med hans Kærlighedlyrik. Denne Paastand turde dog næppe være holdbar. Fra Oprørsaarene findes 6 Digte. Jeg skal ganske kort komme ind paa et Par af de skønneste. Det første er Digtet „Ostern“(5) fra Foraaret 1848. Hvis man læste Digtet uden Forudsætning og ikke havde Tiden og Kampene in mente, vilde man godt kunne glæde sig over den smukke Naturpoesi alene. Digtet er en Skildring af Foraarets Komme til Marskegnene, men man aner Sammenhængen mellem det magtfuldt frembrydende Liv i Naturen og dens kraftige Folkerejsning, der i Øjeblikket gaar hen over Landsdelen. Digteren ønsker endnu mere Fart over Udviklingen og tilraaber Foraarsvinden, der klingende gaar gennem Luften:

Vift, Vaarvind, vift, til hver en Knop er bristet,

Og vi har faaet Sommer helt og fuldt.

Udfold dig, du gudfødte Lys.

Og skælv ej, du mit Hjemlands faste Jord.

I de to sidste Strofer fremkalder Digteren i sin Erindring det samme Landskab, som det ser ud i morke Novembernætter,

5) Storms Sämtliche Werke. Udg af Albert Köster. Bd. I S. 125. 
naar Stormen pisker Havet ind over Digene. Men det kan ikke gennembryde den faste Dæmning, og Digteren udraaber i jublende Triumf over de fjendtlige Kræfters Magtesløshed:

Det Land er vort, og vort det skal forblive.

I Digtet „Im Herbst 1850“7) lyder ikke slet saa begejstrede Toner. Dog forsøger Digteren til Trods for de vanskelige ydre Omstændigheder ${ }^{8}$ ) at holde Modet oppe hos sig selv og sine Meningsfæller. „Selv om Fjenden nu huserer i Hjemstavnen og med brutale Næver river Trikoloren ned fra Soldatergravene, vil han ikke beklage sig, selv om han maaske vil komme til at forlade sit Hjem med Tiggerstaven i Haanden. Han har Bevidstheden om at have gjort sin Pligt:

Til sene Slægter dog vi efterlader

Et tro beseglet Testament.

Og Digteren véd med usvigelig Sikkerhed, at lysere Tider atter vil oprinde for hans Sag.

Thi komme vil det kraftige "Bliv til

Der og for os besejrer Natten.

Den Dag, da denne tyske Jord

Skal ligge i det store Riges Ring.

Fra denne Tid hidrører ogsaa det skønne Digt „Gräber an der Küster ${ }^{\natural}$ ). Digteren skrev det for at hædre Mindet om de Soldater, der blev saaret ved Stormen paa Frederiksstad, og som døde paa Lazarettet i Husum og blev begravet paa den stedlige Kirkegaard.

Digteren giver en fin Skildring af, hvorledes nu de unge Kæmpere hviler ved den hjemlige Kyst. Fra Stranden kommer der en let Brise, som afkøler dem efter den hede Kamp. Havet flammer op i Aftenskæret og kaster sin Glans hen over de mørke Gravhøje. I disse Grave ligger den tyske \#re uplettet. Disse Soldater har reddet Hjemlandet fra Skammen. Nu har

7) Sämtliche Werke Bd. I S. 115.

8) Preussernes Svigten og Danskernes Sejr ved Isted.

๑) Sämtliche Werke Bd. I S. 116. 
de det godt. De „hviler som i Moders Skød“. Men Digteren selv er ikke mere opfyldt af den lyse Tro paa Fremtiden, som prægede hans tidligere Digte.

\section{Men vi, som er tilbage blevet, \\ Hvor i Udlændigheden maa vi dø?}

For Storms Vedkommende var der virkelig Grund til at spørge saaledes. Mørke Skyer var ved at taarne sig op. Da Danskerne definitivt var blevet Herrer i Slesvig-Holsten, var det ganske naturligt, at der blev foretaget en Udrensning. Bl. a. maatte alle Advokaterne i Landsdelen søge om Stadfæstelse af deres Bestalling. Theodor Storms Ansøgning om dette blev afslaaet. I Brevene til sine fortrolige Venner ${ }^{10}$ ) angiver Storm selv, at Grunden var den, at han ved Bruddet mellem Danmark og Hertugdømmerne havde holdt til paa Hjemstavnens Side, og at han havde søgt at værne sine Landsmænd mod Overgreb fra dansk Side.

I et andet $B r{ }^{11}$ ) finder man et Vidnesbyrd om hans Indsats for hans forurettede Klienter. - To ansete Bønder fra Ostenfeld $^{12}$ ) var blevet gennempryglet af de danske Gendarmer (om Grunden dertil forlyder dog intet) og havde henvendt sig til Advokat Storm, for at kan skulde tale deres Sag: „Jeg er lige kommet paa min rette Plads“, skriver Storm, „jeg vil ikke skaane ham, (denne "ham" er Gendarmeriløjtnanten, som, da han erfarede, at man havde meldt Sagen, havde truet Sognefogden med Prygl) det kan han være sikker paa“. Om Sagens Udgang melder Historien intet. - Men ikke alene paa denne Maade havde Storm demonstreret sine tyske Sympatier; ogsaa i Privatlivet lagde han abenlyst sin Mening om de nye Magthavere for Dagen. Dette var saa meget mere uheldigt, som hans Forældre i denne Tid nødtvungent maatte huse en dansk Postmesterfrue. Skønt Storm havde passeret de 30 Aar, var han en

10) Mörike-Storm Briefwechsel. Udg. af J. Bächtold.

11) Briefe an seine Freunde. Udg. af G. Storm 6. 4. 1851.

12) Et Landsogn i Nærheden af Husum. 
ungdommelig Hedspore, der ikke gjorde nogen Røverkule af sit $\mathrm{Hjerte}$. Den danske Dame viderebefordrede hans uforsigtige Ytringer, saa at det blandt Danskerne snart hed sig, at han var "rasende af Patriotisme".

Endvidere havde Storm under Krigen indstillet sin Praksis for at undgaa enhver Kontakt med de dengang indsatte Embedsmænd. Da Krigen var endt, genoptog han sin Gerning. Kort forinden havde han fra Overjustitskommissionen modtaget en Forespørgsel om Grunden til, at han havde indstillet sin Virksomhed. Storm refererer sit Svar til Kommissionen $i$ et Brev til en fortrolig Ven. „Min Erklæring gik ud paa, at jeg, skønt jeg ikke havde deltaget i politisk Virksomhed, dog med mine Følelser og min Overbevisning stod paa mit Hjemlands Side og at jeg allermindst vilde fornægte dette nu. da denne Sag er afsluttet og tabt. Og at jeg derfor havde næret det naturlige Ønske ikke at omgaas de under Krigen indsatte Myndigheder, saa længe denne varede ${ }^{\text {(15). }}$.

Man kunde maaske ogsaa have tænkt sig, at Storms patriotiske Digte var Grunden til Kassationen af hans Embedsbestalling. Men det er yderst tvivlsomt, om disse overhovedet er kommet den danske Regering for $\emptyset_{j}$. De fleste af dem blev nemlig slet ikke trykt i denne Tid. Digtene fra 1850, som er de mest aggressive i Tonen, blev ikke medtaget i den samlede Udgave af Digtene fra 1852, idet Forlæggeren i Kiel ikke vovede at trykke dem.

Jeg har altid syntes, at den danske Regering skred lovligt haardt frem mod Storm ved at fratage ham hans Bestalling, og tyske Biografer ynder at fremstille ham som en Slags Martyr for den slesvig-holstenske Sag. Det er jo ikke nogen Forbrydelse, at man aabent vedkender sig sit nationale Sindelag, naar man iøvrigt optræder loyalt over for Myndighederne. - En Bemærkning i "Sønderjyllands Historie“ foranledigede, at jeg

13) Briefe an seine Freunde 6. 4. 51. 
forsøgte at trænge dybere til Bunds i dette Problem, og mine Undersøgelser gav det Resultat, at Storm ikke var slet saa sagesiøs, som det ifølge hans egne Udtalelser og Biografernes Fremstillinger kunde se ud til. - I Rigsarkivet fandt jeg en Del gamle Dokumenter "Sagen om Advokater fra 1852-62“. I disse Akter var ogsaa Storm senior og juniors Anmodninger om Stadfæstelse af deres Embedsbestallinger behandlet. Baade Amtmanden og Magistraten i Husum har indsendt Rapporter om Advokaterne i deres Embedsdistrikt. Den gamle Storm omtales som „en Ven af Lovlighed og Orden“. Amtmanden mener endog, at det skyldes den gamle Storms Paavirkning af Kommuneforstanderne, at han kun undtagelsesvis i sit Distrikt er stødt paa den ellers ret udbredte passive Modstand. Johann Casimir Storm fik da ogsaa som eneste Advokat i Husum Lov til at fortsætte sin Praksis. - Sønnen bliver endnu udførligen omtalt. Jeg skal ordret citere (i Oversættelse) Amtmandens og Magistratens Indberetninger til Ministeriet for Hertugdømmet Slesvig. Magistratens Udtalelse lyder som følger: „Underretsadvokat Hans Theodor Woldsen Storm. Magistraten kender ikke noget til, at Advokaten skulde have været politisk aktiv før Oprorets Udbrud, og den mener heller ikke, at han har udfoldet en saadan nogensteds. Derimod har han ganske vist under Oprøret paa mangfoldige Maader manifesteret sit slesvigholstenske Sindelag ved at underskrive illoyale Adresser og ved Renitens mod den af den tidligere Landsforvaltning indsatte Øvrighed, den nuværende Amtmand Davids. Han har levet et $\mathrm{i}$ høj Grad tilbagetrukket Liv. Da de kongelige Tropper drog ind i Byen, forblev han der og har siden den Tid forholdt sig rolig og i Overensstemmelse med Loven."

Man vil heraf se, at Magistraten slet ikke er ude paa at skade ham. Den nævner kun de tørre Fakta og fremdrager oven i Købet de Ting, der taler til hans Fordel. Om adskillige af de andre Advokater hedder det, at de flygtede, da Danskerne holdt deres Indtog der. 
Amtmanden W. Johannsens Skrivelse er nærmest en Uddybelse af Magistratens Indberetning. Den har følgende Ordlyd: „Den derværende Magistrat bebrejder Underretsadvokat Hans Theodor Woldsen Storm, at han under Insubordinationen har manifesteret politisk-separatistiske Tendenser ved at underskrive illoyale Adresser og ved Renitens mod den tidligere Landsforvaltning, selv om han i sin i høj Grad tilbagetrukne Tilværelse ikke har gjort sig skyldig i oprørsk Agitation. Denne Anke er ganske vist ikke ubegrundet, thi Advokat Woldsen Storm har i Maj 1849 været Medunderskriver af en illoyal Adresse, der fra flere Indbyggere i Byen Husum blev rettet til den derværende Magistrat. I denne fremsættes en Anmodning om, at det i Byen Husums Navn maa blive erklæret og komme til Landsforvaltningen og Forbundsdagens Kendskab, at Byen ikke mere vilde anerkende Kong Frederilk VII. som SlesvigHolstens Hertug, og at de ønskede Personalunionen med Danmark ophævet for evigt. Endnu under min Embedsførelse har Advokat Woldsen Storm efter egen Tilstaaelse ytret, at han havde suspenderet sin Praksis, indtil de offentlige Forhold var ordnet, hvilket paa given Foranledning bestemte mig til under 12. Februar 1851 at anmode Overjustitskommissionen om, at Advokat Woldsen Storms Tilladelse til at praktisere igen, maatte blive gjort afhængig af, om han vilde udstede et Bevis for, at han vilde anerkende den af Hans Majestæt Kongen allerhøjst indsatte Regeringskommission for Hertugdømmet Slesvig som den eneste retmæssige øverste Regeringsmyndighed i det nævinte Hertugdørmme, og at han ligeledes vilde anerkende samtlige af denne overordentlige Regeringskommission indsatte Justits- og Administrationsmyndigheder som retmæssige Myndigheder, og at han ubetinget vilde folge og adlyde den overordetlige Regeringskommission og de under denne staaende Myndigheders Anmodninger og Resolutioner. - En Resolution oven paa denne min Anmodning er imidlertid ikke paafulgt. Iøvrigt har jeg siden den Tid aldrig haft den mindste Grund til 
Utilfredshed med Advokat Woldsen Storms Adfærd." Og Amtmanden fortsætter efter forskellige Bemærkninger, som ikke er af saa stor Interesse for denne Sag: „Endelig tror jeg at maatte minde om, at jeg først for nylig har faaet Kendskab til den illoyale Adresse fra flere Husum-Indbyggere, som bl. a. Advokaterne Storm, Beccau og Rehder har undertegnet, og at jeg blandt Underskriverne kender enkelte Mænd, som den kgl. Regering ikke har unddraget sin Tillid. Skule der derfor ved Bedømmelsen af Ansøgningerne fra Advokaterne i dette Distrikt om Stadfæstelse af deres Bestallinger blive lagt saa betydelig Vægt paa hin Adresse, at Stadfæstelsen kom til at afhænge af Deltagelse i denne Adresse, saa turde Indsendelse af dette Dokument i Original til det kgl. Ministerium, hvilket jeg indtil nu har anset for det bedste at undlade, være $\mathrm{i}$ høj Grad paakrævet for at undgaa en for uligelig Behandling af dem, som heri har gjort sig skyldig i den samme Forseelse.“

Tilsidst finder man Ministeren for Slesvig Carl Moltkes Afslag paa Ansøgningerne. I Tilfældet Wolden S'torm anfører Ministeren følgende Begrundelse for sit Afslag: „Advokat Hans Theodor Woldsen Storm har underskreven Adresse angaaende Ophævelse af Personalunionen".

Desværre findes denne illoyale Adresse ikke blandt Sagens Akter. Derimod har jeg i Felix Schmeissers Bog: „Eine westschleswigsche Stadt in den Jahren 1848-51" fundet en anden Protestadresse fra en lang Række Husumborgere. Blandt Underskriverne findes ogsaa Advokat Woldsen Storm. Indholdet af denne er følgende: $\mathrm{Vi}$ undertegnede, kommunale Embedsmænd og øvrige Indbyggere i Husum, erklærer herved, at vi protesterer mod de af Landsforvaltningen som en ulovlig Myndighed vedtagne Ophævelse af de bestaaende Love, især af Grundloven, - som en ny, rent vilkaarlig Akt, og at vi nu som før betragter hine Love som gyldige. Husum, den 5. Oktober 1849 .

Storm kunde godt være forblevet i Slesvig. Han kunde 
oven i Købet være indtraadt i den danske Embedsstand, hvis han havde været villig til at underskrive en Erklæring om, at det var hans Forsæt for Fremtiden loyalt at tjene den danske Konge. Men det forbed hans Samvittighed ham. Han drog altsaa i Udlændighed til Preussen. Hans Længsel efter den tabte Hjemstavn kommer til Orde i næsten hele hans digteriske Produktion fra disse Aar. Krigen i 64 affødte atter en Del patriotiske Digte, men efter det Aar lagde han al politisk Digtning paa Hylden.

Storm har haft uhyre lidt Tilknytning til Danmark. Han har ganske vist været i Kongeriget, men hans Besøg indskrænker sig til to Sommerferieophold paa Fovsletgaard ved Kolding, hvis Ejer var beslægtet med Storms anden Hustru. Hans Vurdering af Danskerne er i det store og hele baseret paa de Indtryk, han modtog af dem under og i Aarene umiddelbart efter Krigen, da Mænd fra Kongeriget i stort Tal maatte udfylde de Pladser, der var blevet ledige ved de oprørske Embedsmænds Afsættelse.

Ganske vist anvender Storm, navnlig i sin patriotiske Lyrik, Fjendenavnet om Danskerne, men den Betegnelse, han hyppigst bruger, er "de fremmede“. Man faar uvilkaarligt det Indtryk, at Storm slet ikke er klar over, at Sønderjylland var gammelt dansk Land, og at det til Hælvten var dansktalende. Han mener, at det var den danske Regering om at gøre at faa knægtet den slesvig-holstenske Intelligens. „Jeg har“, skriver han til Mørike, ${ }^{14}$ ) "ligesom næsten alle andre yngre og dygtige Kolleger faaet min Bestalling kasseret, da det er den nuværende Regering særlig magtpaaliggende at tilintetgøre alle Elementer i den uafhængige tyske Dannelse." - Hertil kan man indvende, at Rejsningen jo netop havde haft sit Hovedsæde blandt Akademikerne, saa det var jo en simpel Nødværgeakt fra Statens Side at foretage Udrensningen netop paa det Sted.

14) Storm-Mörike Briefwechsel 12. 7. 53. 
Om Gendarmerne skriver han, at de huserer som smaa "Gesslere" rundt omkring i Landsbyerne. ${ }^{15}$ ) Et andet Sted hedder det, at Borgmesteren har ladet alle Lærerinder sammenkalde og befalet dem for Fremtiden ikke at lade Børnene brodere med broget Uldgarn. Storm mener, at et saadant Træk er betegnende for det danske Regime. Det turde dog nok være et Rygte, som han har faaet galt fat paa. - Hans Aversion mod de danske Embedsmænd gik saa vidt, at han end ikke vilde lade en dansk gejstlig døbe sit Barn. „Hvem vilde lade en hellig Handling foretage paa sit Barn af Mennesker, der træder vor Hjemstavn under Fode?" hedder det $i$ et Brev. ${ }^{16}$ ) Iovrigt ser han med Misbilligelse ogsaa paa den danske Embedsstands Privatliv. Han taler om den „flot levende danske Embedsstand og det lystige overmodige Liv, den fører. ${ }^{17}$ ) De danske Børn kaldes opstadsede. ${ }^{18}$ )

Kontakten med Danmark har afsat forbavsende faa Spor i Storms digteriske Produktion. Ud over de før nævnte patriotiske Digte og et Par Noveller, hvor han ganske kort er inde paa det nationale Modsætningsforhold, strejfer han kun ganske overfladisk Danskernes Karaktertræk. Disse smaa Glimt kunde dog tyde paa, at han har haft den gængse slesvig-holstenske Forestilling om Danskerne som et Folkefærd, der holder af at leve flot og omgive sig med Elegance.

Heller ikke med dansk Aandsliv har Storm været i nogen synderlig Berøring. F. Eks. er de to eneste danske Digtere, han omtaler, Holberg og H. C. Andersen.

Der er i Grunden noget tragisk i, at en dannet Mand, der jo dog levede Halvdelen af sit Liv inden for det danske Monarkis Grænser, havde saa lidt Interesse for og Forstaaelse af dansk Kultur. Men de danske Myndigheder er næppe uden Skyld heri.

15) Briefe an seine Freunde 23. 5. 52.

16) Th. Storms Briefe an Fr. Eggers 13. 8. 56.

17) Th. Fontane: Von Zwanzig bis Dreissig.

18) Gesammelte Werke Bd. II S. 261. 
Naar man gennemblader de Lærebøger, som man benyttede i de faa Timer, der paa Skoleskemaet var afsat til Danskundervsiningen paa den gamle "Gelehrtenschule" i Husum, kan man i alle Tilfælde ikke forbavses over, at Eleverne, som jo for en stor Del udgjorde de vordende Akademikere, ikke følte nogen Trang til senere $i$ Livet at stifte nærmere Bekendtskab med Dansk. De er dødkedelige, rent bortset fra, at de er fulde af grammatiske og ortografiske Fejl.

Kulturelt var Storm saaledes orienteret mod Syd, men politisk var han det egentlig ikke. Da han efter det danske Nederlag i 64 kom tilbage til sin Fødeby, skulde man tro, at han nu vilde have været lykkelig. Men Udviklingen blev ham en stor Skuffelse. Med det bitre Digt "Antwort"10) slutter han sin politiske Digtning.

Nu er det blevet, som du vilde.

Hvorfor tier du da nu?

Det maa Historien berette,

Dog ingen Digters glade Mund.

Det er ejendommeligt, at Storm ikke havde nær saa meget at udsætte paa det danske Styre som paa det preussiske. Brevene til hans fortrolige Venner fra de første Aar efter Hjemkomsten er fyldt med Beklagelser over Preussernes Huseren. Kun en enkelt Udtalelse skal citeres: Det er ikke just behageligt altid at skulle være overfor Vagt mod disse Lomler, der er kommet her til Landet med det tydelige Formaal at bibringe os højere Indsigt og preussisk Lydighed. Tilmed er disse Mennesker, saa vidt jeg kender til dem, i aandelig Henseende ganske ubetydelige .. .. Disse Menneskers naive Raahed er utrolig, og de hjælper bravt med til at gøre den Hadets Fure dybere, som den preussiske Regerings Adfærd har gravet i næsten alle rettænkende Mænds Pande. ${ }^{20}$ )

18) Gesammelte Werke Bd. I S. 125.

20) Storm-Pietsch Briefwechsel og Briefe an seine Freunde. 
Storms Drøm havde været et uafhængigt Slesvig-Holsten, frit for enhver fremmed Indflydelse, hvad enten den kom fra Nord eller Syd. Hele hans digteriske Produktion bærer Vidnesbyrd om hans dybe Kærlighed til Hjemstavnen. Han var, som han et Sted kalder sig selv, „sin Hjemstavns mest trofaste Søn “21.

21) Briefe in die Heimat 5. 12. 63. 